\title{
Disfonia psicogênica associada a outras doenças: desafio para o tratamento fonoaudiológico****
}

\author{
Psychogenic dysphonia associated to other diseases: a challenge for \\ speech therapy
}

\author{
Kátia Nemr* \\ Marcia Simões-Zenari** \\ Suelen Fernanda Marques*** \\ Juliane Pereira Cortez ${ }^{* * * *}$ \\ Andreza Luciane da Silva*****
}

*Fonoaudióloga. Doutora em Psicologia Social pela Universidade de São Paulo (USP). Professora Doutora do Curso de Fonoaudiologia do Departamento de Fisioterapia, Fonoaudiologia e Terapia Ocupacional da Faculdade de Medicina da Universidade de São Paulo (FMUSP). Endereço para correspondência: R. Cipotânea, 51 - São Paulo - SP CEP 05360-160 (knemr@usp.br).

**Fonoaudióloga do Departamento de Fisioterapia, Fonoaudiologia e Terapia Ocupacional da FMUSP. Doutora em Saúde Pública pela Faculdade de Saúde Pública da USP.

***Fonoaudióloga. Bolsista de Capacitação Técnica - Fapesp.

****Fonoaudióloga Clínica. Especialista em Voz pela Santa Casa de Misericórdia de São Paulo.

*****Fonoaudióloga. Aprimoranda do Programa de Aprimoramento do Hospital das Clínicas da FMUSP.

*******Trabalho Realizado no Laboratório de Investigação Fonoaudiológica em Voz do Curso de Fonoaudiologia do Departamento de Fisioterapia, Fonoaudiologia e Terapia Ocupacional da FMUSP.

Artigo de Estudo de Caso

Artigo Submetido a Avaliação por Pares

Conflito de Interesse: não

Recebido em 01.03.2010.

Revisado em 28.06.2010; 30.08.2010.

Aceito para Publicação em 01.09.2010.

\section{Abstract}

Background: success and difficulties in the treatment of psychogenic dysphonia. Aim: to discuss the limitations of speech therapy for psychogenic dysphonia associated with other diseases. Method: evaluation protocols and therapy registrations were used for discussion of the case. Results: the patient arrived with a significant voice change and after evaluation psychogenic dysphonia was diagnosed. The treatment involved vocal activation and modification of the fixed adjustment. Positive changes were observed such as stability in vocal patterns and reduction of hoarseness, roughness, breathiness and throat discomfort and in the quality of life related to voice, but these changes were not sustained since other existing health problems aggravated. Conclusion: speech therapy may be limited, although challenging, when psychogenic dysphonia occurs concomitantly to other diseases.

Key Words: Voice; Voice Disorders; Fibromyalgia.

\section{Resumo}

Tema: sucessos e dificuldades no tratamento de disfonia psicogênica. Objetivo: discutir as limitações da terapia fonoaudiológica para disfonia psicogênica associada a outras doenças. Método: foram utilizados protocolos de avaliação e registros de terapia para discussão do caso. Resultados: a paciente chegou com importante alteração vocal e, após avaliação, diagnosticou-se disfonia psicogênica. O tratamento envolveu ativação vocal e modificação do ajuste fixado. Observaram-se mudanças positivas como estabilidade no padrão vocal, redução da rouquidão, aspereza, soprosidade e desconforto laríngeo e na qualidade de vida relacionada à voz, mas que não se sustentaram na medida em que houve piora dos outros problemas de saúde. Conclusão: o tratamento fonoaudiológico pode ser limitado, contudo desafiador, quando a disfonia psicogênica ocorre de maneira concomitante com outras doenças.

Palavras-Chave: Voz; Distúrbios da Voz; Fibromialgia. 


\section{Introduction}

Psychogenic dysphonias are troubles of psychological nature mainly characterized by vocal alteration without structural larynx lesions or neurological disease, and prevailing for women (1$3)$. Conflicts related with family and work environments may predispose the individual to such alterations $(1,2,4)$. Treatment may involve speech-language therapy, psychotherapy and even transcranial magnetic stimulation $(3,5)$. Patients with this affection would be more susceptible to other diseases of emotional origin (6). Fibromyalgia is highly associated to depression and anxiety (7-9).

Considering that Psychogenic Dysphonia is complex disease, the purpose of this study is reporting and discussing the speech therapy limitations to patients with such diagnosis associated to Fibromyalgia and other diseases.

\section{Method}

This study was approved by the Ethical Committee of the source institution (protocol n. 070/2008). Evaluation protocols and records of speech language therapy sessions in a school-clinic were considered.

\section{Results}

The patient, female, aged 47, came for the speech therapy of such institution where she was undergoing a fibromyalgia treatment. She presented an important voice pattern changed, with a great impact in her life quality.

In the anamnesis has been reported that change of sudden onset, after being intoxicated by chemical products at the hospital where she worked as cleaner. She was displaced from job, and was receiving benefits from Social Security. Reported being treated by several specialists and taking twelve different kinds of medicines a day, due to her large medical historical, besides fibromyalgia: arthrosis, osteoporosis, herniated disc, kidney disease, labyrinthitis, hypertension, depression, anxiety and asthma. She stopped smoking three years ago, after having smoked for 22 years. Several signals and symptoms were related, such as hoarseness, vocal breaking and need of making a great effort to speak, shortness of breath and choking.

During the initial evaluation, the vocal quality was highly unsettled, prevailing breathiness and reaching aphonia. Her indexes of quality of life and voice were altered. Nothing was found at the otorhinolaryngological examination, what may support the hypothesis of simulation.

When she began the speech therapy, she was quite depressed, relating aches and important feeding difficulties associated to nausea. The main focus of the work consisted in vocal activation and changing the patterns established, what showed a good answer. Each new session, the patient arrived for attention presenting the same altered initial pattern, but soon she managed getting out from it, thanks to the therapist's help; she presented longer and longer improvement periods and related several profits in her quality of life. Along the treatment, the psychogenic dysphonia diagnosis was being confirmed $(3,10)$, including her desire of returning to her job. She continued improving a lot, until stabilizing a pattern much better than that initially presented. The other diseases were also controlled, she did not present frequent ache anymore, nor was so depressed.

The discharge from speech therapy was considered and discussed with her, being well accepted, once she seemed having reached her improvement limit. However, in the beginning of the following year, she came back worse in what concerned her voice and general health situation. She began to miss the therapy sessions and to become depressed again. She related she suffered from aches during the sessions, especially due to the kidneys problem and she began to present severe crying crises. She developed a benign tumor in her head, a lipoma, extracted successfully during the same year.

\section{Discussion}

In spite of her effort, the patient reached a peak of improvement which didn't managed to be sustained, due to her fair physical and emotional conditions. She presented important problems, also highlighted by their large quantity. The question of how much represented her "need" of falling ill was considered, next to the psychiatrist who cares her.

Nevertheless, currently she presents a better vocal pattern than she had at the beginning of the treatment and the discharge from speech therapy is being considered again.

\section{Conclusion}

It was possible to reach a stable vocal pattern, with reduction of roughness, breathiness and laryngeal discomfort, but it became compromised by her general health situation. The speech therapy may present several limitations in such cases, although it represents a challenge. 


\section{References}

1. Andersson K, Schaltn L. Etiology and treatment of psychogenic voice disorder: results of a follow-up study of thirty patients. J Voice. 1998;12(1):96-106.

2. Baker J. Psychogenic voice disorders and traumatic stress experience: a discussion paper with two case reports. J Voice. 2003;17(3):308-18.

3. Baker J. The role of psychogenic and psychosocial factors in the development of functional voice disorders. Int $\mathrm{J}$ Speech-Language Pathology. 2008;10(4):210-30.

4. Sudhir PM, Chandra PS, Shivashankar N, Yamini BK Comprehensive management of psychogenic dysphonia: a case illustration. Journal of Communication Disorders. 2009;42:305-12.

5. Chastan N, Parain D, Vérin E, Weber J, Faure MA, Marie JP. Psychogenic aphonia: spectacular recovery after motor córtex transcranial magnetic stimulation. J Neurol Neurosurg Psychiatry. 2009;80(1):94.

6. Rozenthal M, Laks J, Engelhardt E. Aspectos neuropsicológicos da depressão. R. Psiquiatr. 2004;26(2): 204-12.
7. Teng CT, Humes EC, Demetrio FN. Depressão e comorbidades clínicas. Rev. Psiq. Clín. 2005;32(3):14959.

8. Berber JSS, Kupek E, Berber SC. Prevalência de depressão e sua relação com a qualidade de vida em pacientes com síndrome da fibromialgia. Rev Bras Reumatol. 2005;45(2): 47-54

9. Cavalcante AB, Sauer JF, Chalot SD, Assumpção A, Lage LV, Matsutani LA, Marques AP. A prevalência de fibromialgia: uma revisão de literatura. Rev Bras Reumatol. 2006;46(1):40-8

10. Andrade FBF, Azevedo R. Similaridades dos sinais e sintomas apresentados nas disfonias funcionais psicogênicas e nas disfonias com suspeita de simulação: diagnóstico diferencial. Revista Distúrbios da Comunicação. 2006;18 (1):63-73 